\title{
Dried pork meat with different levels of salting
}

\author{
Victor Hugo de Luna DIAS ${ }^{1}$, Terezinha Domiciano Dantas MARTINS², Leonardo Augusto Fonseca PASCOAL ${ }^{2}$, \\ Solange de SOUSA ${ }^{2}$, Neila Lidiany RIBEIRO ${ }^{3 *}$
}

\begin{abstract}
This study's objective was to evaluate the physical-chemical, microbiological, and sensory aspects of pork meat with different levels of salting. Pork from the Duroc and Landrace breeds, with an average live weight of $281 \pm 15.72 \mathrm{~kg}$, were used. The physicochemical data were analyzed following a completely randomized design with four salt addition levels (30, 50, 70, and 90\%). Sensory analysis was performed through a completely randomized design, observing the influence of salt levels in meat. The physical-chemical and sensory variables did not significantly affect $(\mathrm{P}>0.05)$ salt addition, except for cooking loss and water retention capacity. It was concluded that the salt introduction levels of 30 and $50 \%$ are the most appreciated by consumers. The addition of salt levels in the pork meat does not modify the physical-chemical characteristics and the meat's sensory analysis.
\end{abstract}

Keywords: microbiological; salting processing; sensory analysis; TBARs.

Practical Application: Salting is one of the oldest methods used to preserve meat. In the meat industry, incorporating salts into meat products is commonly used to improve dietary functionality and ensure food security.

\section{Introduction}

Food processing allows for a significant variation in the product's final quality, which directly depends on the quality of the raw material used, the processing conditions, storage, and commercialization. Salting is one of the oldest methods used to preserve meat (Inguglia et al., 2017). In the meat industry, incorporating salts into meat products is commonly used to improve dietary functionality. The addition of salts to the meat improves gelling, water binding, fat retention, and cooking loss (Desmond, 2006). However, to improve health, strategies have been investigated to reduce the sodium food content, including the replacement of sodium chloride $(\mathrm{NaCl})$ by other types of salts or by more recent processing techniques (Doyle \& Glass, 2010). A mixture of salts is an excellent strategy to reduce the sodium content in meat products. Some of these mixtures may have potassium chloride, magnesium chloride, essential L-lysine amino acid hydrochloride (Ruusunen \& Puolanne, 2005). Potassium chloride is one of those recent eating techniques used to decrease sodium in foods (Paes \& Ravazi, 2018).

The salted and dried meat products at room temperature best known in Brazil are: sun dried-beef, charqui, and jerked beef (Ferreira et al., 2013), almost always produced with beef. Despite being one of the most consumed industrialized meat products in Brazil, its expansion in the consumer market is far from being fully explored. Its potential goes beyond the domestic market, being a product that does not require the use of the cold chain for its preservation (Abrantes et al., 2014). These products are responsible for adding value to meat production and reducing the environmental impact caused by the by-products' disposal (Toldrá et al., 2012).

The use of meat from older animals to formulate fermented products has lower moisture content and a more pronounced coloring (Silveira \& Andrade, 1991). Discard animals can be used in cooked, smoked, and/or fermented sausages, such as salami (beef, pork, sheep, and goat meat, containing bacon), "Krakauer" (sheep, goat, and pork meat), "iyoner" (product with a composition similar to salami, but without fermentation), Vienna type sausages, ham sausages and hamburger (Zapata, 1994). Another example is the traditional Slovenian sausage "Kranjska klobasa”, smoked and cured with pork (Polak et al., 2017).

The use of salting in meat from discarded swine matrices can be an alternative to improve its utilization since, in addition to incorporating a specific desirable flavor, it can add value to this raw material, which is challenging to sell along with the supply chain beef (Pelegrini et al., 2008). One way of studying these sensory expectations is to apply current methodologies, such as the check-all-that-apply (CATA) test (Nascimento et al., 2020). The sample is presented to the evaluators, along with a list of descriptive terms, from which they are asked to mark all those they believe to describe the sample (Ares et al., 2010). Several recent sensory studies related to the CATA method and food products were made to verify: Nutritional quality and sensory attributes of the date palm drink supplemented with pollen grains (Altamimi et al., 2020) and studied sensory acceptance and check all that apply to mixed juices in different

${ }^{1}$ Programa de Pós-graduação em Tecnologia Agroalimentar, Centro de Ciências Humanas Sociais e Agrárias - CCHSA, Universidade Federal da Paraíba - UFPB, Bananeiras, PB, Brasil

${ }^{2}$ Departamento de Ciência Animal, Centro de Ciências Humanas Sociais e Agrárias - CCHSA, Universidade Federal da Paraíba, Bananeiras, PB, Brasil

${ }^{3}$ Instituto Nacional do Semiárido, Campina Grande, PB, Brasil

*Corresponding author: neila.ribeiro@insa.gov.br 
Brazilian regions (Nascimento et al., 2020). Records on pork jerky are scarce in the literature. Thus, this study's objective was to evaluate pork meat's physical-chemical, microbiological, and sensory aspects with different salting levels.

\section{Materials and methods}

\subsection{Experiment site and animals}

The Animal Ethics Committee approved this study of the Federal University of Paraiba (UFPB), Brazil (protocol no. 079/17). The experiments were performed at the Federal University of Paraíba (UFPB) located in the city of Bananeiras, Paraíba, Brazil $\left(6^{\circ} 41^{\prime} 11^{\prime \prime} \mathrm{S}\right.$ and $\left.35^{\circ} 37^{\prime} 41^{\prime \prime} \mathrm{W}\right)$.

For the pork jerky preparation, raw material from the random slaughter of discarded female hogs, of the Duroc and Landrace breeds, with an average live weight of $281.00 \pm 15.72 \mathrm{~kg}$, was used.

\subsection{Processing of pork jerky}

1. Boning: Ribs and pieces of the belly were used to make beef jerky. The ribs were manually dissected, removing the bones. Excess subcutaneous and intermuscular fat and connective tissue were also removed in the selected parts. The two cuts were joined to obtain $42 \mathrm{~kg}$ of raw material per treatment;

2. Wet salting: The blankets were previously taken to a water tank containing a brine solution produced by adding $185 \mathrm{~kg}$ of sodium chloride in 700 liters of water, corresponding to $26.42 \%$ of salt when a solution was reached $24^{\circ}$ Baumé;

3. Dry salting: the blankets were stacked on pallets covered with plastic wrap, with the greased side facing down. Among the blankets, sodium chloride was applied in the amounts of $6.3,10.5,14.7$, and $18.9 \mathrm{~kg}$ of NaCl , corresponding to the percentage used for each of the experimental treatments with $\mathrm{NaCl}$ contents $30,50,70$, and $90 \%$, remaining 24 hours;

4. Re-salting: The overflow was carried out with the same $\mathrm{NaCl}$ content as in the previous period, obeying the levels within the same treatment, also ensuring the disposition in the different layers of the blanket, thus remaining for another 24 hours;

5. Tip: The pieces were inverted and subjected to a rest period of 24 hours;

6. Wash: The blankets were taken to the wash tank. The tank contained treated water $(200 \mathrm{~L})$ and added salt $(20 \mathrm{~kg})$, corresponding to $10 \%$. Each blanket remained in the tank until the excess salt was removed, after which they were taken to rest, with water drained for 24 hours, being sent to the drying line;

7. Drying: The blankets were exposed to the sun and wind under the greenhouse protection. In the late afternoon, the blankets were kept at a temperature of $25^{\circ} \mathrm{C}$. The drying process lasted 72 hours;
8. Pressing and packaging: The blankets were pressed with an average force of $382 \mathrm{~N}$ for 12 hours. Finally, they were deformed, cut into three parts, and vacuum packed in plastic bags for a specific use.

The environment temperature and the air's relative humidity were monitored during the pork jerky processing, obtaining the average values described in Table 1.

The pieces were kept in a controlled environment at an average temperature of $24.8^{\circ} \mathrm{C}$ and average relative humidity of $65.1 \%$ (maximum of $27.0^{\circ} \mathrm{C}$ and minimum of $22.5^{\circ} \mathrm{C}$ and relative humidity of $73.8 \%$ of maximum and $56.4 \%$ of minimum) until the analysis that obeyed the $0,30,60$ and 90 days.

In each treatment, we work with $42 \mathrm{~kg}$ of meat in which salts have been added in increasing proportions (30,50,70, and $90 \%$ ), with the levels of salt being added in its processing in the proportions of $15,25,35$ and $45 \%$ for the salting process and added $15,25,35$ and $45 \%$ for the re-salting process.

\subsection{Physicochemical analysis}

The final $\mathrm{pH}(5.94)$ and the final temperature $\left(5.5^{\circ} \mathrm{C}\right)$ were measured with the aid of the $\mathrm{pH}$ meter measured on the rib after 24 hours (pH24) and analyzed the objective color measured with the aid of a portable colorimeter type Minolta Chroma Meter regarding the luminosity $\left(\mathrm{L}^{*} ; 0=\right.$ Black, $100=$ White $)$, and twocolor coordinates $\mathrm{a}^{*}$ (red) and $\mathrm{b}^{\star}$ (yellow), obtaining an average of 44.40 for L, 8.55 for a and 11.91 for b, respectively. Moreover, a hygrometer was used to determine the water activity.

Cooking losses (CLs) were evaluated according to the methodology described by Wheeler et al. (1975). Two steaks of $2.5 \mathrm{~cm}$ thickness were obtained from the pork jerky. Steaks were thawed in a refrigerator for $24 \mathrm{~h}$ and weighed using a precision balance. Then, samples were placed together in a griddle and baking sheet and roasted in an electric oven, preheated to $150{ }^{\circ} \mathrm{C}$ (Fischer, Star model, Brusque, Santa Catarina, Brazil), the internal temperature of the samples reached $70^{\circ} \mathrm{C}$. Samples were cooled at room temperature until the samples reached an internal temperature of $25^{\circ} \mathrm{C}$, measured using an insertion thermometer. Samples were then weighed to determine the weight loss, which was expressed as weight loss percentage.

Table 1. Average indexes of air temperature and relative humidity in the processing stages of pork jerky.

\begin{tabular}{lcccccc}
\hline \multirow{2}{*}{ Processors } & \multicolumn{2}{c}{ Average temperature $\left({ }^{\circ} \mathrm{C}\right)$} & & \multicolumn{2}{c}{ Relative humidity (\%) } \\
\cline { 2 - 3 } \cline { 5 - 6 } & Máximum & Mínimum & & Máximum & Mínimum \\
\hline Dry salting & 26.4 & 25.1 & & 80.5 & 77.5 \\
Bounce & 25.7 & 20.2 & & 86.0 & 66.0 \\
Stack back & 26.6 & 26.1 & & 76.0 & 73.5 \\
Tipping & 26.5 & 24.7 & & 81.5 & 71.5 \\
Washing & 25.9 & 21.8 & & 78.0 & 74.5 \\
1st Drying & 43.0 & 31.1 & & 51.5 & 34.0 \\
2nd Drying & 36.5 & 28.9 & & 51.5 & 51.5 \\
3rd Drying & 38.9 & 30.1 & & 42.0 & 39.0 \\
\hline
\end{tabular}


A texture analyzer (G-R Manufacturing CO, Model 3000 TAXT2, Stable Micro Systems, Godalming, UK) was used. Seven pieces of meat of $1 \mathrm{~cm} \times 1 \mathrm{~cm} \times 2.5 \mathrm{~cm}$ (height $\times$ width $\times$ length) were removed parallel to the muscle fiber direction. Samples were wholly cut using a Warner Bratzler shear blade with a triangular slot cutting edge ( $1 \mathrm{~mm}$ thickness) at a cut speed of $20 \mathrm{~cm} \mathrm{~min}^{-1}$. As shown by the more great peak of the force-time curve, maximum shear force represented the sample's maximum resistance to the cut.

Moisture, protein, fat, and ashes content were determined according to Association of Official Analytical Chemists (2010). The determination of chlorides in $\mathrm{NaCl}$ was carried out through the ashes by the argentometry method, which is used to analyze animal's origin products (Brasil, 1981).

\subsection{Lipid oxidation}

For the lipid oxidation analysis, the 2-thiobarbituric acid reactive substances test (TBARs) assay was used, being pork jerky analyzed during four storage periods (weeks) with intervals of 20 days (Tarladgis et al., 1960). The lipid determination was made by the method previously described by Folch et al. (1957) was used to extract the fat from the food with chloroform and methanol at the proportion of 2:1.

\subsection{Microbiological analysis}

These samples were analyzed by duplicate. The microbial analysis was performed according to recommendations by the RDC Resolution Number 12 of January 2, 2001, and the samples were analyzed according to the methodology described by the American Public Health Association (2001) to determine total coliforms, thermotolerant coliforms, viable aerobic mesophilic bacteria, coagulase-positive Staphylococcus and Salmonella sp. The analyses of total and thermotolerant coliforms were performed following the technique of the most probable number. The depth plate technique analysis of viable aerobic mesophilic bacteria was performed using Plate Count Agar and incubation at $35 \pm 2{ }^{\circ} \mathrm{C}$ for a period of $48 \mathrm{hr}$. Coagulase positive Staphylococcal analyses were performed by direct plate counting. The plates were incubated in an oven at $36^{\circ} \mathrm{C}$ for 48 hours, and then the plates were collected to count the colonies. For the analysis of Salmonella sp. the procedure was as follows: a pre-enrichment of the samples with lactose broth and incubation at $42 \pm 2{ }^{\circ} \mathrm{C}$ for $24 \mathrm{hr}$ was carried out, and then a selective enrichment with Tetrionate and Selenite cysteine broth followed by incubation in xylose lysine deoxycholate agar and Enteric Agar was done.

\subsection{Check-All-That-Apply (CATA) test}

The sensorial quality (color, appearance, tenderness, flavor, odor, and overall acceptance) of each beverage product was measured using a 9-points unstructured Descriptive Analysis scale ( $1=$ immensely dislike and $9=$ remarkably like). A structured hedonic nine-point scale, ranging from 1 - "strongly disliked" to 9 - "strongly liked," was used to assess overall acceptance (Meilgaard et al., 2007; Nascimento et al., 2020).
The pork jerky samples were cut into uniform cube shapes to weigh approximately 10 to $15 \mathrm{~g}$. Then, they were placed in trays type marinex and taken to a preheated oven at a temperature of $270{ }^{\circ} \mathrm{C}$, for 30 minutes, being turned in the first 15 minutes to homogenize the samples better.

The potatoes, English type, were cooked in boiling water without the addition of salt. After cooling, they were peeled and cut into slices to be served to the evaluators to clean the samples' taste. All samples, in triplicate, were made available simultaneously in $50 \mathrm{~m}$ polyethylene cups, encoded with three random digits for each experimental treatment. The evaluators were instructed to taste one at a time, from left to right, and use the baked potato to clean the palate and mineral water to wash the mouth after each analysis (Macfie et al., 1989).

Sensory analysis was performed in individual booths with controlled environmental conditions at a temperature of around $23^{\circ} \mathrm{C}$ (International Organization for Standardization, 1988). The panel included eight agricultural science students who were duly selected and trained (International Organization for Standardization, 1993). The tests took place in one session and eleven trained tasters.

A scale of 5 points recommended by Meilgaard et al. (2007) was used to evaluate the intention of purchasing: 1 (Certainly I would buy it); 2 (Probably I would buy it); 3 (Maybe I would buy it/Maybe I would not buy it); 4 (Probably I would not buy it) and 5 (Certainly I would not buy it).

\subsection{Statistical analysis}

The experimental design was completely randomized (DIC) with four treatments. The data were subjected to analysis of variance (ANOVA), and the means compared by the Tukey test at $5 \%$ probability, using the PROC GLM and the regression analysis using the PROC REG of the SAS statistical package (Statistical Analyses System, 2001). The Ryan - Einot - Gabriel - Welsch test was used for sensory analysis at a significance level of $5 \%$.

After standardization, a multivariate analysis test was carried following the recommendations previously established by Sneath \& Sokal (1973) to allocate the animals into groups according to similarity and verify the original traits' discriminatory power. The principal component analysis (PCA) allowed the overall variance assessment; it was performed by the PRINCOMP procedure, separately for each population.

Besides, discriminant analysis was performed to describe the variation among groups, identifying those traits with the best discriminatory power.

\section{Results and discussion}

\subsection{Physicochemical analysis}

The different levels of salt inclusion in pork did not significantly influence $(\mathrm{P}>0.05)$ moisture, ash, protein, lipids, $\mathrm{AW}, \mathrm{pH}, \mathrm{SF}$, chlorides $\mathrm{NaCl}$, and TBARs (Table 2). There was a significant effect $(\mathrm{P}<0.05)$ for the inclusion of different salt levels in pork for WHC and CL. 
Original Article

Salted pork

Table 2. Physico-chemical variables of pork jerky subjected to different levels of salting.

\begin{tabular}{|c|c|c|c|c|c|c|c|}
\hline \multirow{2}{*}{ Variable } & \multicolumn{4}{|c|}{ Levels of salt inclusion in the pork jerky (\%) } & \multirow{2}{*}{ SEM } & \multicolumn{2}{|c|}{$P$-value } \\
\hline & 30 & 50 & 70 & 90 & & Linear & Quadratic \\
\hline Moisture (\%) & 38.19 & 37.19 & 35.43 & 36.61 & 7.06 & 0.472 & 0.592 \\
\hline Ash (\%) & 19.54 & 19.01 & 18.98 & 17.51 & 4.27 & 0.265 & 0.702 \\
\hline Protein $(\%)$ & 25.79 & 26.19 & 25.62 & 27.78 & 2.31 & 0.768 & 0.799 \\
\hline Fat $(\%)$ & 20.46 & 25.67 & 23.02 & 20.84 & 2.75 & 0.888 & 0.114 \\
\hline$A_{w}$ & 0.75 & 0.75 & 0.74 & 0.75 & 0.02 & 0.669 & 0.265 \\
\hline $\mathrm{pH}$ & 5.37 & 5.58 & 5.52 & 5.59 & 0.25 & 0.076 & 0.336 \\
\hline CL (\%) & $19.45 c$ & $37.48 \mathrm{a}$ & $34.51 \mathrm{ab}$ & $26.67 \mathrm{bc}$ & 3.75 & 0.610 & $0.004^{1}$ \\
\hline $\mathrm{SF}\left(\mathrm{kgf} \mathrm{cm} \mathrm{cm}^{-2}\right)$ & 10.75 & 10.58 & 9.70 & 10.73 & 1.99 & 0.918 & 0.529 \\
\hline WHC (\%) & $69.64 \mathrm{~b}$ & $78.16 \mathrm{a}$ & 73.64ab & $76.58 \mathrm{a}$ & 2.21 & 0.095 & 0.490 \\
\hline $\mathrm{NaCl}$ & 5.26 & 5.17 & 6.32 & 4.11 & 1.59 & 0.797 & 0.459 \\
\hline TBARs & 0.26 & 0.26 & 0.28 & 0.32 & 0.09 & $0.019^{2}$ & 0.343 \\
\hline
\end{tabular}

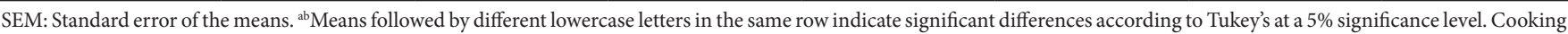
loss (CL); Shear force (SF); Water holding capacity (WHC). ${ }^{1} \mathrm{Y}=-35.02+2.36 \mathrm{x}-0.02 \mathrm{x}^{2}\left(\mathrm{R}^{2}=0.85\right) ;{ }^{2} \mathrm{Y}=0.22+0.001 \mathrm{x}\left(\mathrm{R}^{2}=0.83\right)$.

It is observed that the humidity was stable at the different levels of salting (35.43 - 38.19\%) and above what is recommended by the Ministry of Agriculture. According to the Ministry of Agriculture, Agriculture, and Supply (Brasil, 2001), the pork jerky should not have more than 35\% moisture and 15\% fixed mineral, tolerating a variation of up to $5 \%$.

The average water activity was around $0.75 \%$. Youssef et al. (2003) indicated that the pork jerky samples' water activity at time zero was 0.77 . The jerky must have water activity between 0.70 and 0.75 (Lira \& Shimokomaki, 1998), as it has a salt concentration of around 15\%. Food processing has the function of preventing deterioration, which affects the acceptance of food by the consumer. The deterioration of food is associated with the water content available for physical-chemical, biochemical and microbiological changes (Molina et al., 2006).

The average values of protein and lipids (26.35 and 18.98\%, respectively) (Table 2) did not vary between treatments of different salting levels. The results are explained by the excellent material raw used in the process. As may also have happened due to the curing process that causes the meat to absorb salt, curing agents, and other medium components, losing its substances, proteins, among others, to the brine (Coró et al., 2020).

The $\mathrm{pH}$ showed an average of 5.52 (Table 2) and was considered suitable for the development of cured products (Gutierrez, 2008). According to Costa-Corredor et al. (2010), the meat's initial $\mathrm{pH}$ affects the absorption of ions during the salting process, not in the post-salting process, because there is a sodium/potassium compensation. Behavior different from that of this research is observed by Purriños et al. (2011), who found an increase in chloride content with salt.

The sheer force did not show any significant difference between the treatments of inclusion of salting, with an average value of $10.68 \mathrm{kgf}$. According to Silva et al. (2004), evaluating the effect of salting on the SF of sheepshank obtained values of 11.66 and $16.04 \mathrm{kgf}$ for salty products with $15 \%$ and $20 \%$, respectively. This variation in softness depends on many factors, such as muscle type, the industrial process applied, sample preparation, cooking method, instrumental measurement process used; in the case of this research, it can be seen in Table 2 that this SF value did not affect the excellent grade given in the texture attribute.

The cooking loss increased with 50 and $70 \%$ salt and was lower at 30 and $90 \%$. It presented a quadratic effect with its highest value at the level of $50 \%$ inclusion of salt in the meat. The cooking loose was considered harmful for industry and consumers, as, according to Bonagurio et al. (2002), the nutritional quality of meat reduces soluble proteins, vitamins, and minerals and reduces palatability.

The water retention capacity showed a treatment effect ( $\mathrm{P}<0.05)$ according to salt's inclusion. The salting level of $90 \%$ showed higher water retention in the meat, being different from $70 \%$ salting and similar to $30 \%$ and $50 \%$. The WRC presented an average value of $81.97 \%$, the muscle with high WRC offers high value in sensory characteristics such as juiciness and tenderness (Universidade Estadual de Campinas, 2011). The effect of sodium chloride on WRC is associated with increased pressure on the protein matrix. The salt increases the WRC, viscosity, and stability of the fat, forming a stable emulsion, which gives the consumer a sense of succulence (Desmond, 2006). According to Medyński et al. (2000), there is a reduction in drip losses and an increase in WRC when sodium chloride is added.

\subsection{Lipid oxidation}

The TBARs had a linear regressive effect, with a more excellent value at $90 \%$ of salt inclusion in the meat. The value of TBARs is essential, as quality physical-chemical parameters are considered in matured and fermented meat products. TBARs values up to $1.59 \mathrm{mg}$ of malonaldehyde $/ \mathrm{kg}$ of the sample were considered low to be perceived by sensory analysis and are not harmful to human health. Most volatile compounds responsible for pork jerky's typical aroma come from lipid oxidation reactions during processing (Gianelli et al., 2012).

The salt added during the manufacture of various meat products has been held responsible as a catalyst for lipid oxidation, increasing the number of TBARs as seen in this research 
(Asghar et al., 1990). Lipid oxidation has been considered one of the main problems associated with the deterioration and loss of meat products' quality during storage. These reactions cause changes related to the loss of essential fatty acids, vitamins, the formation of toxic compounds (malonaldehydes and cholesterol oxides), and the deterioration of color, aroma, and flavor parameters, consequently affecting the nutritional and sensory value of the food (Souza et al., 2007).

\subsection{Microbiological analysis}

Regarding microbiological analysis (Table 3), no growth was detected in the meat with salt.

It was observed that the microbiological quality of the product followed the recommendations of the legislation (RDC 12, of January 02, 2001), the values being stipulator for coliforms at $45^{\circ} \mathrm{C}$, Staphylococcus and Salmonella sp./25 g of $10^{3}$ NMP.g- ${ }^{-1}, 5 \times 10^{3}$ UFC.g- ${ }^{1}$, and absent (Brasil, 2001). According to Franco \& Landgraf (2008), the determination of deteriorating and pathogenic microorganisms in salted meat serves as a basis for establishing microbiological standards.

All treatments showed an absence of Salmonella sp. According to Desmond (2006), it is vital to examine the shelf life and microbiological safety of processed meat products before reducing or replacing $\mathrm{NaCl}$ by other ingredients.

\subsection{Sensory analysis}

The different levels of salt in pork jerky did not significantly influence $(\mathrm{P}>0.05)$ the sensory parameters (Table 4$)$.

Concerning the image of a product, the consumer's perception of quality and value determines their purchase and choice options. According to Huffman et al. (1996), for the tasters to observe changes in meat tenderness between samples, a variation of at least one kgf between them is necessary. In the present study, this variation was 0.94 , restricting the panel's discriminative capacity. According to Silva et al. (2004), there is an inverse relationship between the proportion of $\mathrm{NaCl}$ and meat tenderness.

Considering the Kramer and Friedman test (Minim, 2006), there is no significance between the samples for the analysis of ordering by preference. Regarding the purchase intention, it is observed that the highest percentage of evaluators defined that they would certainly buy pork jerky with different levels of salting. This characteristic was chosen by 39 (28\%), 38 (27\%), $34(24 \%)$ and 29 (21\%) evaluators, in the treatments of 30, 50, 70 and $90 \%$, respectively. A smaller number of evaluators said

Table 3. Effect of adding different levels of pork salting on microbial counts of pork jerky.

\begin{tabular}{lcccc}
\hline \multirow{2}{*}{\multicolumn{1}{c}{ Microorganisms }} & \multicolumn{5}{c}{$\begin{array}{c}\text { Levels of salt inclusion in the pork } \\
\text { jerky (\%) }\end{array}$} \\
\cline { 2 - 5 } & 30 & 50 & 70 & 90 \\
\hline Coliform $35^{\circ} \mathrm{C}$ & $<3.0$ & $<3.0$ & $<3.0$ & $<3.0$ \\
Coliform $45^{\circ} \mathrm{C}$ & $<3.0$ & $<3.0$ & $<3.0$ & $<3.0$ \\
Staphylococcus spp. $\left(\mathrm{UFC} \mathrm{g}{ }^{-1}\right)$ & $<100$ & $<100$ & $<100$ & $<100$ \\
Salmonella sp. $(25 \mathrm{~g})$ & Absent & Absent & Absent & Absent \\
\hline
\end{tabular}

they would certainly not buy pork jerky with different levels of salting. This characteristic was chosen by 5 (18\%), 6 (21\%), 7 $(25 \%)$, and $10(36 \%)$ of the evaluators in the treatments of 30 , 50,70 , and $90 \%$, respectively.

Most of the evaluators interviewed would certainly buy jerky pork with 30 and 50\% salt. Most reviewers would certainly not buy jerky pork with $90 \%$ salt. The use of low salt levels $(30$ and 50\%) in the meat of old animals (discard animals) was sufficient for the evaluators to accept the product's purchase. This inclusion of salt added flavor and value to the raw material that is difficult to sell.

\subsection{Multivariate analysis}

Two main components were needed to explain $63.21 \%$ of the data's total variation regarding the characteristics studied (Table 5). The percentage of accumulated variation in the first factor was $48 \%$, represented by the variables: appearance, color, flavor, tenderness, and odor, being directly proportional.

Figure 1 shows us an inverse relationship between general acceptability and the other variables. It is worth mentioning that the purchase intention was influenced by salt to pork (Figure 1). The second component represented $14 \%$ of the variables' total variation and is represented by the general acceptability attribute. The purchase intention was not represented in any of the two components, showing less importance among the characteristics

Table 4. Sensory attributes of pork jerky with different levels of salt inclusion.

\begin{tabular}{lcccccc}
\hline \multirow{2}{*}{ Variables } & \multicolumn{9}{c}{ Levels of salt inclusion in the pork } & \multirow{2}{*}{ jerky (\%) } & PEM \\
\cline { 2 - 5 } & 30 & 50 & 70 & 90 & & \\
\hline Appearance & 7.28 & 7.18 & 7.16 & 7.19 & 1.56 & NS \\
Colour & 7.11 & 6.94 & 6.91 & 7.02 & 1.59 & NS \\
Tenderness & 6.94 & 7.03 & 6.94 & 6.33 & 1.76 & NS \\
Odor & 6.89 & 7.07 & 6.59 & 6.78 & 1.70 & NS \\
Flavor & 7.08 & 7.33 & 7.12 & 6.88 & 1.80 & NS \\
$\begin{array}{l}\text { Overall } \\
\text { acceptability }\end{array}$ & 7.28 & 7.10 & 7.10 & 7.22 & 2.75 & NS \\
$\begin{array}{l}\text { Purchase } \\
\text { intention }\end{array}$ & 6.90 & 6.89 & 5.80 & 5.50 & 1.20 & NS \\
\hline
\end{tabular}

SEM: Standard error of the means. ${ }^{\mathrm{a}, \mathrm{b}}$ Different letters on the line differ from each other by Ryan - Einot - Gabriel - Welsch test at $5 \%$ probability.

Table 5. Factor loading of the sensory attributes evaluated in pork jerky.

\begin{tabular}{lcc}
\hline Variable & PC1 & PC2 \\
\hline Appearance & $\mathbf{0 . 7 9 5 1 1 9}$ & -0.036933 \\
Colour & $\mathbf{0 . 8 2 7 5 0 9}$ & -0.058889 \\
Flavor & $\mathbf{0 . 8 5 2 9 3 8}$ & 0.136017 \\
Tenderness & $\mathbf{0 . 7 9 7 0 3 7}$ & 0.042622 \\
Odor & $\mathbf{0 . 7 5 3 2 1 4}$ & 0.061024 \\
Overall acceptability & 0.032651 & 0.991958 \\
Purchase intention & 0.403538 & $\mathbf{0 . 0 1 7 5 8 4}$ \\
Eigenvalues of the correlation matrix $(\lambda)$ & 3.410998 & 1.013163 \\
Total variance explained by components $(\%)$ & 48.88 & 14.33 \\
\hline Bold values indicates $p<0.05$. Principal component $=$ PC. &
\end{tabular}




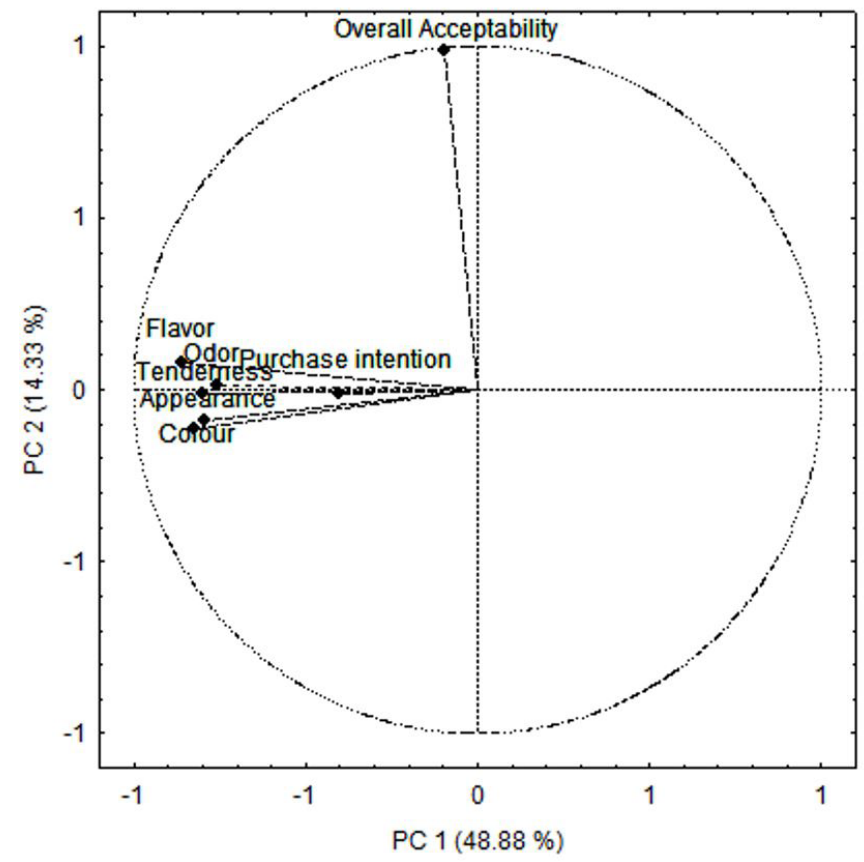

Figure 1. Principal components (PC) of the sensory attributes evaluated in pork jerky.

studied in this experiment. It was also the variable that received lower scores, as can be seen in Table 4 .

\section{Conclusion}

The addition of different salt levels in the discarded matrix pork does not modify the physical-chemical characteristics and the pork jerky's sensory analysis. The microbiological characteristics were within the norms of the legislation. The dried pork meat has good acceptability in the market, and those with 30 and 50\% of salting are the most appreciated by consumers.

\section{References}

Abrantes, M. R., Sousa, A. C. P., Araújo, N. K. S., Sousa, Ê. S., Oliveira, A. R. M., \& Silva, J. B. A. (2014). Avaliação Microbiológica de carne de charque produzida industrialmente. Arquivos do Instituto Biológico, 81(3), 282-285. http://dx.doi.org/10.1590/1808-1657000942012.

Altamimi, J. Z., Alfaris, N. A., Almousa, L. A., Abu-Hiamed, H. A., Albadr, N. A., \& Alghamdi, F. A. (2020). Nutritional quality and sensory attributes of date palm spathes beverage supplemented with pollen grains. Food Science and Technology, 40(Suppl. 2), 728-732. http://dx.doi.org/10.1590/fst.00420.

American Public Health Association - APHA. (2001). Compendium of methods for the microbiological examination of foods (4th ed.). Washington.

Association of Official Analytical Chemists - AOAC. (2010). Official methods of analysis (18th ed., 1094 p.). Washington.

Ares, G., Deliza, R., Barreiro, C., Giménez, A., \& Gámbaro, A. (2010). Comparison of two sensory profiling techniques based on consumer perception. Food Quality and Preference, 21(4), 417-426. http:// dx.doi.org/10.1016/j.foodqual.2009.10.006.
Asghar, A., Torres, E., Gray, J. I., \& Pearson, A. M. (1990). Effect of salt on myoglobin derivatives in the sarcoplasmic extract from pre- and post rigor beef in the presence orabsence of mitochondria and microsomes. Meat Science, 27(3), 197-209. http://dx.doi. org/10.1016/0309-1740(90)90051-7. PMid:22055285.

Bonagurio, S., Perez, J. R. O., Garcia, I. F. F., Bressan, M. C., \& Lemos, A. L. C. (2002). Qualidade da carne de cordeiros Santa Inês Puros e mestiços com Texel abatidos com diferentes pesos. Revista Brasileira de Zootecnia, 32, 9-104.

Brasil, Ministério da Agricultura, Pecuária e Abastecimento, Laboratório Nacional de Referencia Animal - LANARA. (1981, October 13). Métodos analíticos oficiais para controle de produtos de origem animal e seus ingredientes (Portaria $\mathrm{n}^{\circ} 001 / 81$, de 7 de outubro de 1981). Diário Oficial [da] República Federativa do Brasil.

Brasil. (2001, July 16). Regulamento o técnico de identidade e qualidade de manteiga da terra, queijo de coalho e queijo de manteiga (Instrução Normativa no 30 de 26 de junho de 2001). Diário Oficial [da] República Federativa do Brasil.

Coró, F. A. G., Gaino, V. O., Carneiro, J., Coelho, A. R., \& Pedrão, M. R. (2020). Control of lipid oxidation in jerked beef through the replacement of sodium nitrite by natural extracts of yerba mate and propolis as an antioxidant agent. Brazilian Journal of Development, 6(1), 4834-4850. http://dx.doi.org/10.34117/ bjdv6n1-348.

Costa-Corredor, A., Muñoz, I., Arnau, J., \& Gou, P. (2010). Ion uptakes and diffusivities in pork meat brine-salted with $\mathrm{NaCl}$ and $\mathrm{K}$-lactate. Lebensmittel-Wissenschaft + Technologie, 43(8), 1226-1233. http:// dx.doi.org/10.1016/j.lwt.2010.03.018.

Desmond, E. (2006). Reducing salt: A challenge for the meat industry. Meat Science, 74(1), 188-196. http://dx.doi.org/10.1016/j. meatsci.2006.04.014. PMid:22062728.

Doyle, M. E., \& Glass, K. A. (2010). Sodium reduction and its effect on food safety, food quality, and human health. Comprehensive Reviews in Food Science and Food Safety, 9(1), 44-56. http://dx.doi. org/10.1111/j.1541-4337.2009.00096.x. PMid:33467812.

Ferreira, V. C. S., Martins, T. D. D., Batista, E. S., Santos, E. P., Silva, F. A. P., Araújo, I. B. S., \& Nascimento, M. C. O. (2013). Physicochemical and microbiological parameters of dried salted pork meat with different sodium chloride levels. Food Science and Technology, 33(2), 382-386. http://dx.doi.org/10.1590/S010120612013005000055.

Folch, J., Less, M., \& Stanley, S. (1957). A simple method for the isolation and purification of total lipids from animal tissues. The Journal of Biological Chemistry, 226(1), 497-509. http://dx.doi.org/10.1016/ S0021-9258(18)64849-5. PMid:13428781.

Franco, B. D. G. M., \& Landgraf, M. (2008). Microbiologia dos alimentos. São Paulo: Atheneu.

Gianelli, M. P., Salazar, V., Mojica, L., \& Friz, M. (2012). Volatile compounds present in traditional meat products (charqui and longaniza sausage) in Chile. Brazilian Archives of Biology and Technology, 55(4), 603-612. http://dx.doi.org/10.1590/S1516-89132012000400017.

Gutierrez, J. B. (2008). Jamón Curado: aspectos científicos y tecnológicos. Perspectivas desde la Unión Europea. España: Díaz de Santos.

Huffman, K. L., Miller, M. F., Hoover, L. C., Wu, C. K., Brittin, H. C., \& Ramsey, C. B. (1996). Effect of beef tenderness on consumer satisfaction with steaks consumed in the home and restaurant. Journal of Animal Science, 74(1), 91-97. http://dx.doi.org/10.2527/1996.74191x. PMid:8778116.

Inguglia, E. S., Zhang, Z., Tiwari, B. K., Kerry, J. P., \& Burgess, C. M. (2017). Salt reduction strategies in processed meat products: 
a review. Trends in Food Science \& Technology, 59, 70-78. http:// dx.doi.org/10.1016/j.tifs.2016.10.016.

International Organization for Standardization - ISO. (1988). ISO 8589: sensory analysis: general guidance for the design of test rooms. Geneva: ISO.

International Organization for Standardization - ISO. (1993). ISO 8586-1: sensory analysis: general guidance for the selection, training, and monitoring of assensors: part 1: selected assessors. Geneva: ISO.

Lira, G. M., \& Shimokomaki, M. (1998). Parâmetros da qualidade da carne de sol e dos charques. Revista Higiene Alimentar, 44, 66-69.

Macfie, H. J., Bratchell, N., Greenhoff, K., \& Vallis, L. V. (1989). Designs to balance the effect of order of presentation and first-order carryover effects in hall tests. Journal of Sensory Studies, 4(2), 129-148. http://dx.doi.org/10.1111/j.1745-459X.1989.tb00463.x.

Medyński, A., Pospiech, E. E., \& Kniat, R. (2000). Effect of various concentrations of lactic acid and sodium chloride on selected physicchemical meat traits. Meat Science, 55(3), 285-290. http://dx.doi. org/10.1016/S0309-1740(99)00153-9. PMid:22061284.

Meilgaard, G. K., Civille, G. V., \& Carr, B. I. (2007). Sensory evalution techniques: marketing and R\&D approaches (4th ed.). Boca Raton: CRC Press.

Minim, V.P.R. (2006). Análise sensorial: estudos com consumidores. Viçosa: UFV.

Molina, L. Fo., Pedro, M. A. M., Telis-Romero, J., \& Barboza, S. H. R. (2006). Influência da temperatura e da concentração do cloreto de sódio $(\mathrm{NaCl})$ nas isotermas de sorção da carne de tambaqui (Colossoma macroparum). Food Science and Technology, 6(2), 453458. http://dx.doi.org/10.1590/S0101-20612006000200032.

Nascimento, R. Q., Tavares, P. P. L. G., Meireles, S., Anjos, E. A., Andrade, R. B., MacHado, B. A. S., Souza, A. L. C., \& Mamede, M. E. O. (2020). Study and sensory acceptance and check all that apply of mixed juices in distinct Brazilian regions. Food Science and Technology, 40(Suppl. 2), 708-717. http://dx.doi.org/10.1590/fst.37619.

Paes, J. A. S., \& Ravazi, R. F. (2018). Técnicas para redução de sódio nos alimentos industrializados. REGRAD - Revista Eletrônica de Graduação do UNIVEM, 11, 379-390.

Pelegrini, L. F. V. D., Pires, C. C., Terra, N. N., Campagnol, P. C. B., Galvani, D. B., \& Chequim, R. M. (2008). Elaboration of fermented sausage type salami using meat from culling ewe. Food Science and Technology, 28, 150-153. http://dx.doi.org/10.1590/S010120612008000500023.

Polak, T., Lušnic Polak, M., Tomović, V. M., Žlender, B., \& Demšar, L. (2017). Characterization of the kranjska klobasa, a traditional Slovenian cooked, cured, and smoked sausage from coarse ground pork. Journal of Food Processing and Preservation, 42(6), e13269. http://dx.doi.org/10.1111/jfpp.13269.

Purriños, L., Bermúdez, R., Temperán, S., Franco, D., Carballo, J., \& Lorenzo, J. M. (2011). Influence of salt content and processing time on sensory characteristics of cooked "lacón". Meat Science, 87(4), 436-442. http://dx.doi.org/10.1016/j.meatsci.2010.11.022. PMid:21168978.

Ruusunen, M., \& Puolanne, E. (2005). Reducing sodium intake from meat products. Meat Science, 70(3), 531-541. http://dx.doi.org/10.1016/j. meatsci.2004.07.016. PMid:22063751.

Silva, A. G. S. So., Zeola, N. M. B. L., Souza, H. B. A., \& Lima, T. M. A. (2004). Qualidade da carne ovina submetida ao processo de salga. Food Science and Technology, 24(3), 369-372. http://dx.doi. org/10.1590/S0101-20612004000300011.

Silveira, E. T. F., \& Andrade, J. (1991). Aspectos tecnológicos de processamento e qualidade de embutidos fermentados. Campinas: FEA/UNICAMP.

Sneath, P. H., \& Sokal, R. R. (1973). Numerical taxonomy: the principles and practice of numerical classification. Systematic Zoology, 24, 263-268.

Souza, A. R. M., Arthur, V., \& Canniatti-Brazaca, S. G. (2007). Efeito da radiação gama e do armazenamento na oxidação lipídica e no colesterol de carne de cordeiros da raça Santa Inês. Food Science and Technology, 27(1), 67-71. http://dx.doi.org/10.1590/S010120612007000100012.

Statistical Analyses System - SAS. (2001). Statistical Analysis System user's guide. Version 9.2. Cary: Statistical Analyses System Institute.

Tarladgis, B. G., Watts, B. M., Younathan, M. T., \& Dugan, L. Jr. (1960). A distillation method for the quantitative determination of malonaldehyde in rancid foods. Journal of the American Oil Chemists' Society, 37(1), 44-48. http://dx.doi.org/10.1007/BF02630824.

Toldrá, F., Aristoy, M. C., Mora, L., \& Reig, M. (2012). Innovations in value addition of edible meat by-products. Meat Science, 92(3), 290 296. http://dx.doi.org/10.1016/j.meatsci.2012.04.004. PMid:22560456.

Universidade Estadual de Campinas - UNICAMP. (2011). TACO Tabela Brasileira de Composição de Alimentos (4. ed.). Campinas.

Wheeler, T. T., Cundiff, L. V., \& Koch, R. M. (1975). Effects of marbling degree on palatability and caloric content of beef. Beef Research Program Progress Report, 71(4), 133-134.

Zapata, J. F. F. (1994). Tecnologia e comercialização da carne ovina. In Anais da Semana da Caprinocultura e da Ovinocultura Tropical Brasileira. Brasília: EMBRAPA-SPI.

Youssef, E. Y., Garcia, C. E. R., \& Shimokomaki, M. (2003). Effect of Salt on Color and Warmed over Flavor in Charqui Meat Processing. Brazilian Archives of Biology and Technology, 46, 595-600. 